\title{
Sex hormone suppression and sexual impotence in hypoxic pulmonary fibrosis
}

\author{
P D'A SEMPLE, GH BEASTALL, TM BROWN, KW STIRLING, RJ MILLS, WS WATSON \\ From the Chest Unit, Inverclyde Royal Hospital, Greenock; Department of Steroid Biochemistry and Centre \\ for Respiratory Investigation, Royal Infirmary, Glasgow; and Department of Clinical Physics and \\ Bioengineering, Southern General Hospital, Glasgow
}

ABSTRACT Eight men with hypoxia associated with idiopathic pulmonary fibrosis were studied. Serum testosterone concentrations were low in two subjects and fell to subnormal levels in two others as the clinical condition and arterial oxygen tension deteriorated. There was a significant correlation between serum testosterone concentrations and arterial oxygen tensions $(p<0.05)$. Three patients showed evidence of suppression of luteinising hormone secretion at the pituitary level. Only occasional abnormalities of thyroid and prolactin concentrations were noted. Most of the men suffered from organic sexual impotence, which is considered to be due at least in part to endocrine disturbance. These findings are similar to observations in patients with hypoxic chronic obstructive airways disease and support the hypothesis that hypoxia of lung disease suppresses the hypothalamo-pituitary-testicular axis.

While studying metabolic aspects of chronic obstructive lung disease we found reduced serum testosterone values in affected men ${ }^{1}$ and were able to show an association between severity of hypoxia and degree of testosterone suppression. ${ }^{2}$ In subsequent studies we showed suppression of the hypothalamus or pituitary or both and not of the testes themselves to be responsible ${ }^{3}$ and other aspects of endocrine function to be comparatively normal. Such changes were reversible, improving with a rise in arterial oxygen tension in patients recovering from acute exacerbations with cor pulmonale. ${ }^{4}$ These hormone abnormalities had not previously been described in such patients, although low levels of urinary 17 ketosteroids had been noted at high altitude, indicating reduced testosterone production in the hypoxia of altitude, ${ }^{5}$ and also in emphysema. ${ }^{6}$ We have shown that organic sexual impotence can be a consequence of such low anabolic steroid production.? As there have been no reported studies of the hypothalamo-pituitary-testicular axis or sexual function in other clinical conditions characterised by hypoxia we set out to study a group of men with hypoxia secondary to pulmonary fibrosis.

\footnotetext{
Address for reprint requests: Dr P d'A Semple, Chest Unit, Inverclyde Royal Hospital, Greenock PA16.
}

Accepted 16 September 1983

\section{Methods}

Approval for the project was granted by the hospital ethical committee and informed written consent was obtained from all patients. Eight men attending a chest clinic who were considered to have radiographic evidence of pulmonary fibrosis were invited to participate. All had fine late inspiratory crackles and in no case was an aetiological factor incriminated. Severity of breathlessness was gauged with the help of the Medical Research Council questionnaire on respiratory symptoms ${ }^{8}$ and the six married patients under the age of 70 were asked questions relating to their sexual function. Lung function studies included measurement of $\mathrm{FEV}_{1}$ and forced vital capacity (FVC), residual volume and total lung capacity (TLC) (helium dilution method), and single breath transfer factor (TLCO). The results obtained $\sigma$ were compared with predicted normal values. ${ }^{910} \mathrm{~N}$ Arterial blood samples for gas analysis were taken $N$ from the radial artery after the patient had been ${ }^{\omega}$ lying down resting for 15 minutes and breathing room air. Patients found to have an arterial carbon dioxide tension greater than $6.0 \mathrm{kPa}(45 \mathrm{~mm} \mathrm{Hg}) \stackrel{\mathbb{\leftrightarrow}}{\rightarrow}$ were excluded.

Within one week of these baseline investigations the patients had a pituitary stimulation test per- $\overrightarrow{\mathbb{D}}$ formed, all at about the same time of day $(10.30 \stackrel{\odot}{\oplus}$ am-12 noon). Gonadotrophin releasing hormone $\frac{\varrho}{0}$ 
$(100 \mu \mathrm{g})$ and thyrotrophin releasing hormone $(20$ $\mu \mathrm{g})$ (Relefact LH-RH/TRH, Hoechst) were injected intravenously. Blood samples were taken at standard time intervals and stored at $-20^{\circ} \mathrm{C}$ before assay. All serum hormone measurements were made by radioimmunoassay methods. Serum follicle stimulating hormone and luteinising hormone concentrations were obtained according to procedures recommended by the supraregional assay service, prolactin was measured by the method of Cowden $e t$ $a l,{ }^{11}$ and thyroid stimulating hormone was measured by a modification of the method of Hall et al, ${ }^{12}$ a rabbit antihuman thyroid stimulating hormone serum kindly donated by Professor WR Butt being used. The reference standards for follicle stimulating hormone, luteinising hormone, prolactin, and thyroid stimulating hormone assays were MRC 69/ $104,68 / 40,75 / 504$, and $68 / 38$ respectively. Thyroxine and triiodothyronine were measured with semiautomated radioimmunoassays ${ }^{13}$ using second antibody separation. Testosterone was measured in diethyl ether extracts of serum with an antibody that has about $20 \%$ cross reactivity with $5 \alpha$ dihydrotestosterone.

Our laboratory's normal data for all of these methods have been obtained from appropriate volunteer hospital inpatient populations. The correlation between serum testosterone and arterial oxygen tension was tested by a least sum of squares linear fit.

\section{Results}

The results of pulmonary function tests and resting blood gas tensions are shown in table 1 . In all cases the $F E V_{1} / F V C$ ratio was $70 \%$ or greater, excluding significant airways obstruction. In all patients both TLC and TLCO were less than $80 \%$ of predicted normal values, in keeping with a diagnosis of pulmonary fibrosis. In addition, all subjects were hypoxic and normocapnic. Subjects 2 and 8 were each studied a second time several months later, when clinical deterioration accompanied by a drop in arterial oxygen tension $\left(\mathrm{PaO}_{2}\right)$ was observed. Subject 2 was not sufficiently well to have his TLC and TLCO measured on the second occasion. Dyspnoea at rest (grade 4) was present in most of the patients (table 2). The only patient with minimal dyspnoea (No 7) had the highest $\mathrm{PaO}_{2}$.

Of the six married men under 70 , four admitted that they had had diminished libido for periods of six months to three years accompanied by infrequent or absent early morning penile erections, while subject 3 had had normal libido despite absence of early morning erections for years (table 2). In those with suppressed libido coitus was infrequent and, when achieved, it tended to be unsatisfactory, with either unsatisfactory or absent orgasm. The prospect of dyspnoea induced by coitus often played some part in suppressing libido.

Two subjects (Nos 1 and 4) had frankly subnormal serum testosterone concentrations, while the values for two others (Nos 2 and 8 ) became subnormal ( $2 b$ and $8 b$ ) with clinical deterioration (table $3)$. There was a significant correlation $(p<0.05)$ between serum testosterone and $\mathrm{PaO}_{2}$ (fig). Serum hormone binding globulin values were slightly raised in four of the six patients in whom it was measured. The serum luteinising hormone and follicle stimulating hormone response to injected gonadotrophin releasing hormone was not tested in subject 1 . Three of the other subjects (Nos 2b, 3, and 4) had subnormal luteinising hormone responses, and two of these (Nos 3 and 4) also had subnormal follicle stimulating hormone responses. An initial high basal luteinising hormone concentration was noted in sub-

Table 1 Results of pulmonary function tests and resting arterial blood gas tensions

\begin{tabular}{|c|c|c|c|c|c|c|c|}
\hline $\begin{array}{l}\text { Patient } \\
\text { No }\end{array}$ & $\underset{(y)}{\text { Age }}$ & $\begin{array}{l}F E V_{1} \\
\text { (\% pred) }\end{array}$ & $\underset{(\%)}{F E V, / F V C}$ & $\begin{array}{l}T L C \\
\text { (\% pred) }\end{array}$ & $\begin{array}{l}\text { TLCO } \\
\text { (\% pred) }\end{array}$ & $\begin{array}{l}\mathrm{PaO}_{2} \\
(\mathrm{kPa})\end{array}$ & $\begin{array}{l}\mathrm{PaCO}_{2} \\
(\mathrm{kPa})^{2}\end{array}$ \\
\hline $\begin{array}{l}1 \\
2 \mathrm{a} \\
\mathrm{b} \\
3 \\
4 \\
5 \\
6 \\
7 \\
8 \mathrm{a} \\
\mathrm{b}\end{array}$ & $\begin{array}{l}35 \\
45 \\
45 \\
59 \\
72 \\
50 \\
41 \\
53 \\
56 \\
56\end{array}$ & $\begin{array}{l}39 \\
47 \\
30 \\
68 \\
90 \\
34 \\
61 \\
83 \\
44 \\
44\end{array}$ & $\begin{array}{l}83 \\
70 \\
84 \\
82 \\
73 \\
92 \\
73 \\
83 \\
72 \\
80\end{array}$ & $\begin{array}{l}40 \\
79 \\
56 \\
78 \\
39 \\
69 \\
66 \\
43 \\
44\end{array}$ & $\begin{array}{l}20 \\
19 \\
74 \\
29 \\
49 \\
67 \\
67 \\
56 \\
44\end{array}$ & $\begin{array}{r}6 \cdot 1 \\
8 \cdot 3 \\
6 \cdot 1 \\
9 \cdot 9 \\
7 \cdot 2 \\
7 \cdot 6 \\
10 \cdot 1 \\
10 \cdot 3 \\
7 \cdot 7 \\
4 \cdot 4\end{array}$ & $\begin{array}{l}4 \cdot 7 \\
4 \cdot 1 \\
4 \cdot 3 \\
4 \cdot 5 \\
4 \cdot 4 \\
3 \cdot 8 \\
5 \cdot 2 \\
6 \cdot 0 \\
4 \cdot 8 \\
4 \cdot 3\end{array}$ \\
\hline
\end{tabular}

$\mathrm{FEV}_{1}$ - forced expiratory volume in one second; FVC - forced vital capacity; TLC - total lung capacity; TLco-single breath transfer factor; $\mathrm{PaO}_{2}$, and $\mathrm{PaCO}_{2}$ - partial pressure in arterial blood of oxygen and carbon dioxide; \% pred-percentage of predicted normal value; ${ }^{10} 2 \mathrm{a}, \mathrm{b}$ and $8 \mathrm{a}, \mathrm{b}$-patients studied on two separate occasions. 
Table 2 Clinical, sexual, and drug histories of patient with pulmonary fibrosis

\begin{tabular}{|c|c|c|c|c|c|}
\hline \multirow{2}{*}{$\begin{array}{l}\text { Patient } \\
\text { No }\end{array}$} & \multirow{2}{*}{$\begin{array}{l}\text { Dyspnoea } \\
\text { grade }\end{array}$} & \multicolumn{3}{|c|}{ Sexual history } & \multirow[t]{2}{*}{ Drugs } \\
\hline & & $\begin{array}{l}\text { Diminished } \\
\text { libido }\end{array}$ & $\begin{array}{l}\text { Early am } \\
\text { erection }\end{array}$ & $\begin{array}{l}\text { Time since last } \\
\text { coitus }\end{array}$ & \\
\hline $\begin{array}{l}1 \\
2 \mathrm{a} \\
\mathrm{b}\end{array}$ & $\begin{array}{l}4 \\
3 \\
4\end{array}$ & $\begin{array}{l}\text { Yes-3 y } \\
\text { Yes-31/2 y }\end{array}$ & $\begin{array}{l}\text { No-2 y } \\
\text { No }\end{array}$ & $\begin{array}{l}1 \mathrm{~m} \\
6 \mathrm{~m}\end{array}$ & $\begin{array}{l}\text { Prednisolone } 40 \mathrm{mg} \\
\text { None } \\
\text { Prednisolone } 10 \mathrm{mg} \text {, digoxin } 0.25 \mathrm{mg} \text {, } \\
\quad \text { frusemide } 40 \mathrm{mg} \text {, spironolactone } 200 \mathrm{mg}\end{array}$ \\
\hline $\begin{array}{l}3 \\
4 \\
5\end{array}$ & $\begin{array}{l}3 \\
4 \\
4\end{array}$ & $\begin{array}{l}\text { No } \\
\text { Yes-7 m }\end{array}$ & $\begin{array}{l}\text { No-? duration } \\
\text { No-6 } \mathrm{m}\end{array}$ & $1 \mathrm{~m}$ & $\begin{array}{l}\text { None } \\
\text { None } \\
\text { Prednisolone } 10 \mathrm{mg} \text {, cyclophosphamide } \\
\quad 60 \mathrm{mg}\end{array}$ \\
\hline $\begin{array}{l}6 \\
7 \\
8 a \\
b\end{array}$ & $\begin{array}{l}4 \\
1 \\
4 \\
4\end{array}$ & $\begin{array}{l}\text { Yes-1 y } \\
\text { No } \\
\text { Yes-6 m } \\
\text { Yes-9 m }\end{array}$ & $\begin{array}{l}\text { No-1 y } \\
\text { Yes } \\
\text { Less regular } \\
\text { No }\end{array}$ & $\begin{array}{l}1 \mathrm{~m} \\
<1 \mathrm{w} \\
2 \mathrm{w} \\
>3 \mathrm{~m}\end{array}$ & $\begin{array}{l}\text { None } \\
\text { None } \\
\text { None } \\
\text { Prednisolone } 40 \mathrm{mg} \text {, azathioprine } 200 \mathrm{mg} \text {, } \\
\text { bendrofluazide } 10 \mathrm{mg}\end{array}$ \\
\hline
\end{tabular}

Table 3 Anterior pituitary function in men with hypoxic pulmonary fibrosis: basal testosterone values and gonadotrophin concentrations after injection of gonadotrophin releasing hormone

\begin{tabular}{|c|c|c|c|c|c|c|c|c|}
\hline \multirow{2}{*}{$\begin{array}{l}\text { Patient } \\
\text { No }\end{array}$} & \multirow{2}{*}{$\begin{array}{l}\text { Basal } \\
\text { serum } 17 \mathrm{OHA} \\
\text { (nmolll) }\end{array}$} & \multirow{2}{*}{$\begin{array}{l}\text { Basal } \\
\text { SHBG } \\
\text { (nmolll) }\end{array}$} & \multicolumn{3}{|c|}{ Serum LH (mU/l): minutes after $G n R h$} & \multicolumn{3}{|c|}{ Serum FSH (mU/l): minutes after GnRH } \\
\hline & & & 0 & 30 & 60 & 0 & 30 & 60 \\
\hline $\begin{array}{l}1 \\
2 a \\
b \\
3 \\
4 \\
5 \\
6 \\
7 \\
8 a \\
\text { b } \\
\text { Normal } \\
\text { values }\end{array}$ & $\begin{array}{c}9 \cdot 0 \\
18 \\
4 \cdot 0 \\
15 \\
4 \cdot 0 \\
20 \\
18 \\
19 \\
22 \\
5 \cdot 2 \\
11-36\end{array}$ & $\begin{array}{l}- \\
\overline{13} \\
46 \\
18 \\
55 \\
- \\
\overline{54} \\
50 \\
5-45\end{array}$ & $\begin{array}{c}6 \cdot 6 \\
5 \cdot 2 \\
3 \cdot 0 \\
4 \cdot 5 \\
6 \cdot 9 \\
20 \\
15 \\
4 \cdot 6 \\
6 \cdot 1 \\
5 \cdot 2 \\
\text { UD-9.0 }\end{array}$ & $\begin{array}{r}-30 \\
12 \\
14 \\
12 \\
>100 \\
27 \\
>30 \\
20 \\
22 \\
20-42\end{array}$ & $\begin{array}{r}\overline{27} \\
11 \\
17 \\
11 \\
>100 \\
11 \\
>30 \\
23 \\
19 \\
20-38\end{array}$ & $\begin{array}{c}2 \cdot 7 \\
4 \cdot 5 \\
4 \cdot 9 \\
2 \cdot 4 \\
3 \cdot 1 \\
20 \\
3 \cdot 1 \\
3 \cdot 2 \\
5 \cdot 2 \\
4 \cdot 1 \\
\text { UD-7.0 }\end{array}$ & $\begin{array}{c}\overline{25} \\
17 \\
3 \cdot 4 \\
4 \cdot 2 \\
>30 \\
5 \cdot 4 \\
13 \\
6.9 \\
7 \cdot 4 \\
4-18\end{array}$ & $\begin{array}{c}\overline{24} \\
15 \\
3 \cdot 4 \\
4 \cdot 3 \\
>30 \\
5 \cdot 3 \\
13 \\
9 \cdot 2 \\
6 \cdot 5 \\
4 \cdot 5-21\end{array}$ \\
\hline
\end{tabular}

GnRH-gonadotrophin releasing hormone; 17 OHA-17 hydroxyandrogens (testosterone); SHBG-serum hormone binding globulin; LH-luteinising hormone; FSH-follicle stimulating hormone; UD-undetectable.

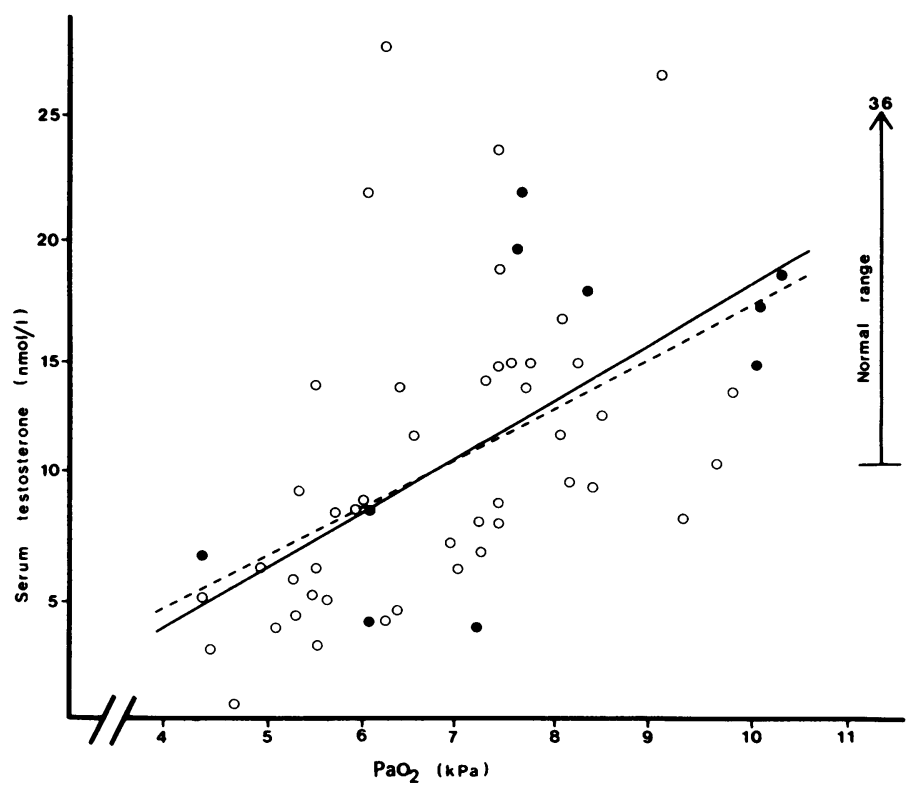

Correlation between arterial oxygen tension and serum testosterone in patients with hypoxic pulmonary fibrosis (closed circles, solid line; $n=10, r=0.682, p<$ $0.05)$. Measurements from previously reported studies of patients with chronic obstructive lung disease $1^{-3}$ have been superimposed (open circles, dotted line; $n$ $=45, r=0.473, p<0.01$ ). Conversion: SI to traditional units-Arterial oxygen tension $1 \mathrm{kPa}=7.5 \mathrm{~mm} \mathrm{Hg}$. 
Sex hormone suppression and sexual impotence in hypoxic pulmonary fibrosis

Table 4 Anterior pituitary function in men with hypoxic pulmonary fibrosis: basal thyroid function and thyroid stimulating hormone and prolactin response to injection of thyrotrophin releasing hormone

\begin{tabular}{|c|c|c|c|c|c|c|c|c|}
\hline \multirow{2}{*}{$\begin{array}{l}\text { Patient } \\
\text { No }\end{array}$} & \multirow{2}{*}{$\begin{array}{l}\text { Basal serum } \\
T_{3}(\text { nmolll })\end{array}$} & \multirow{2}{*}{$\begin{array}{l}\text { Basal serum } \\
T_{4}(\text { nmolll })\end{array}$} & \multicolumn{3}{|c|}{ Serum TSH (mU/l): minutes after TRH } & \multicolumn{3}{|c|}{ Serum prolactin (mU/l): minutes after TRH } \\
\hline & & & 0 & 30 & 60 & 0 & 30 & 60 \\
\hline $\begin{array}{l}1 \\
2 a \\
b \\
3 \\
4 \\
5 \\
6 \\
7 \\
8 a \\
b \\
\text { Normal } \\
\text { range }\end{array}$ & $\begin{array}{l}2.4 \\
1.8 \\
1.7 \\
2.1 \\
1.4 \\
2.3 \\
2.1 \\
1.7 \\
1.6 \\
1.6 \\
0.9-2.8\end{array}$ & $\begin{array}{c}130 \\
110 \\
55 \\
90 \\
75 \\
72 \\
108 \\
82 \\
70 \\
123 \\
55-144\end{array}$ & $\begin{array}{l}3.4 \\
1.9 \\
5.9 \\
2.1 \\
1.2 \\
2.1 \\
1.6 \\
2.3 \\
3.7 \\
2.6 \\
\text { UD-8.0 }\end{array}$ & $\begin{array}{c}6 \cdot 9 \\
9 \cdot 9 \\
31 \\
11 \\
5 \cdot 8 \\
14 \\
6 \cdot 1 \\
16 \\
12 \\
12 \\
\text { Increr } \\
30>\end{array}$ & $\begin{array}{c}4 \cdot 6 \\
5 \cdot 3 \\
20 \\
9 \cdot 4 \\
4 \cdot 3 \\
8 \cdot 9 \\
4 \cdot 4 \\
17 \\
11 \\
8 \cdot 9 \\
6^{8 \cdot 9}\end{array}$ & $\begin{array}{l}410 \\
110 \\
590 \\
78 \\
250 \\
250 \\
110 \\
98 \\
200 \\
300 \\
60-360\end{array}$ & $\begin{array}{l}990 \\
220 \\
820 \\
350 \\
530 \\
840 \\
260 \\
440 \\
760 \\
580 \\
\text { Incre } \\
30>\end{array}$ & $\begin{array}{c}560 \\
110 \\
690 \\
230 \\
450 \\
520 \\
150 \\
2600 \\
630 \\
380 \\
5 \% \text { of basal }\end{array}$ \\
\hline
\end{tabular}

TSH-thyroid stimulating hormone; TRH-thyrotrophin releasing hormone; $\mathrm{T}_{3}$-triiodothyronine; $\mathrm{T}_{4}$-thyroxine; UD-undetectable.

jects 5 and 6 and a high basal follicle stimulating hormone concentration in subject 5 . Normal serum triiodothyronine and thyroxine values were obtained in all subjects (table 4). Rather flat thyroid stimulating hormone response curves between 30 and 60 minutes after injection of thyrotrophin releasing hormone were observed in subjects 7 and $8 \mathrm{a}$. The basal serum prolactin concentration was moderately raised in subjects 1 and $2 b$. There was a delayed prolactin response to injected thyrotrophin releasing hormone in subject 7 .

\section{Discussion}

We have shown that in hypoxic pulmonary fibrosis hormone changes are essentially similar to those we have already reported in chronic obstructive lung disease. ${ }^{1-3}$ In both conditions serum testosterone tends to be low in proportion to the degree of hypoxia (fig) and is not related to the concentration of hormone binding globulin, which is normal or modestly raised. Elevation of hormone binding globulin concentration may be secondary to low serum testosterone concentrations and this would tend to reduce the free testosterone values even further. Suppression of the hypothalamo-pituitarytesticular axis has again been demonstrated but in some patients with pulmonary fibrosis the disturbance appears to originate at pituitary rather than hypothalamic level, as evidenced by a diminished response of both luteinising hormone and follicle stimulating hormone to injected gonadotrophin releasing hormone in patients 3 and 4 .

Subject 5, a comparatively young man, had high basal luteinising hormone and follicle stimulating hormone values (table 3 ) in the presence of normal serum testosterone, a picture seen in primary testicular failure as in Klinefelter's syndrome and sometimes in elderly men. ${ }^{14}$ This is not a feature we have noticed previously in hypoxic lung disease. Possibly cyclophosphamide treatment was responsible for the high gonadotrophin concentrations in this patient as this drug damages testicular germinal (Sertoli) cells with consequent oligospermia, ${ }^{15}$ although normal endocrine function is usually preserved. ${ }^{16}$ Acute exposure to hypoxia at high altitude is known to induce changes in the testicular germinal epithelium of animals ${ }^{17}$ and produce oligospermia in rams $^{18}$ and men ${ }^{19}$ and urinary output of testosterone after injection of human chorionic gonadotrophin is decreased in natives of high altitude regions. ${ }^{20}$ All this evidence supports the possibility of testicular suppression in those circumstances. A fall in luteinising hormone, however, has also been noted in acute exposure to high altitude $^{21}$ and so it seems possible that either the hypothalamus, the pituitary, or the testis alone may on occasion be the primary organ to fail in conditions of hypoxia.

In both of the chronic lung conditions we have studied, serum testosterone levels tend not to fall below normal until the $\mathrm{PaO}_{2}$ drops below $7.3 \mathrm{kPa}$ $(55 \mathrm{mmHg})^{1-4}$ (fig). The four patients with pulmonary fibrosis who had the lowest testosterone and lowest $\mathrm{PaO}_{2}$ values had died by the time of writing so it appears that a low serum testosterone concentration, like a low arterial oxygen tension, is an unfavourable feature. This was also our impression in our patients with chronic obstructive lung disease.

Unlike subject 2 , subject 8 retained normal luteinising hormone and follicle stimulating hormone responses as his condition deteriorated with falling $\mathrm{PaO}_{2}$ but by this time he was in hospital receiving intermittent oxygen treatments, which may have improved hypothalamo-pituitary-testicular function. It will be of some interest to find out 
whether oxygen treatment can prevent or even reverse these hormone changes.

In our studies so far we have found nothing to contradict the hypothesis that hypoxia is the offending agent accounting for the hormone changes. Hypercapnia, which was present in many of our patients with chronic obstructive lung disease with suppression of the hypothalamo-pituitary-testicular axis, cannot be incriminated as it was absent in all of the patients with pulmonary fibrosis. Reviewing those of the seven patients with recovery from exacerbations of chronic obstructive lung disease with cor pulmonale in which serum testosterone and $\mathrm{PaO}_{2}$ values rose, ${ }^{4}$ we found that arterial carbon dioxide tension fell in four but rose in three, which again makes hypercapnia an unlikely culprit. Although arterial $\mathrm{pH}$ tended to fall with recovery, values were within or near the normal range and $\mathrm{pH}$ therefore seems unlikely as a factor. Conceivably acid-base changes could influence the hypothalamo-pituitary-testicular axis as base excess did fall significantly with recovery. Hypothalamopituitary-testicular abnormalities are not, however, recognised features of acid-base changes in other clinical conditions. Corticosteroid suppression of the hypothalamo-pituitary-testicular axis has been described in Cushing's disease ${ }^{22}$ but we have no reason to believe that steroid treatment is responsible in hypoxic chest disease. Our own unpublished observations suggest that patients with nonrespiratory disease retain normal testosterone values even when taking a $50 \mathrm{mg}$ daily dose of prednisolone. Moreover, subject 4 in the present study had a low serum testosterone concentration but was taking no drugs, and few among our hypoxic patients with chronic obstructive lung disease who had low serum testosterone concentrations were taking oral steroids. Furthermore, we have noted an appreciable increase in serum testosterone in patients recovering from cor pulmonale, ${ }^{4}$ commensurate with the rise in $\mathrm{PaO}_{2}$, despite the fact that such patients were often taking no drugs on admission in the acute phase but on recovery were taking several drugs, including spironolactone-which has been alleged to cause a reduction in serum testosterone. ${ }^{23}$

The hypothalamo-pituitary-thyroid axis appears to be comparatively well preserved in pulmonary fibrosis as it is in patients with chronic obstructive lung disease, ${ }^{13}$ although we did find the occasional instance of delayed thyroid stimulating hormone response to injected thyrotrophin releasing hormone in both syndromes. Such delayed thyroid stimulating hormone and prolactin responses are thought to indicate hypothalamic damage, ${ }^{12}$ but these fairly new tests of hypothalamo-pituitary func- tion are still being evaluated and such results should be interpreted with caution. Occasional instances of non-drug-induced modest increases in serum prolactin were found in both respiratory conditions, but these changes are known to occur with any physical or emotional stress and the drugs used were not ones usually associated with increased prolactin concentrations. ${ }^{24}$

It is not surprising to find evidence of reduced sexual function in this group of men with a tendency to testosterone deficiency. We had found evidence of loss of libido in nine of our 10 patients with chronic obstructive lung disease and it was a feature of most of our men with pulmonary fibrosis. This is clearly an unusual finding since $90 \%$ of men aged 50-60 years practise regular coitus or similar sexual activity and have regular early morning penile erections, ${ }^{2526}$ and lack of such erections is generally taken as a guide in distinguishing organic from psychological causes of impotence..$^{26-28}$ Most patients with chronic obstructive lung disease thought that diminished libido was not related to the prospect of dyspnoea during the exertion of intercourse, whereas in the patients with pulmonary fibrosis this factor did appear to accentuate the problem. Subjects 3,5 , and 6 had no early morning erections despite normal serum testosterone concentrations (table 2). We have shown that libido and sexual performance can fluctuate with the severity of disease and also with changes in arterial oxygen tension and serum testosterone. ${ }^{7}$ Possibly when they were studied patients 3,5 , and 6 were comparatively well from the respiratory standpoint and this may have been reflected in near normal endocrine activity. Previously we have indicated that organic sexual impotence may not be an "all or none" phenomenon ${ }^{29}$ and normal serum testosterone concentrations do not necessarily reflect a normal hypothalamopituitary-testicular axis. ${ }^{3}$

In conclusion, low serum testosterone concentrations and sexual impotence occur in men with hypoxic pulmonary fibrosis as well as in hypoxic chronic obstructive lung disease. Significant correlations between $\mathrm{PaO}_{2}$ and serum testosterone in both conditions suggest a causal relationship, particularly as there is no evident relationship between other arterial blood gas indices and serum testosterone. The hypothesis that hypoxia itself suppresses the hypothalamo-pituitary-testicular axis remains to be tested. Pituitary stimulation tests in pulmonary fibrosis suggest that pituitary suppression may be responsible for the deficient steroidogenesis in some cases whereas in chronic obstructive lung disease the suppression was apparently hypothalamic. One case of possible testicular suppression in pulmonary fibrosis was noted. Pituitary rather than 
hypothalamic suppression of follicle stimulating hormone release occurs in both conditions, though we have no information on spermatogenesis or fertility. Minor suppression of the hypothalamopituitary-thyroid axis seems to occur in both conditions but in neither is it sufficient to cause clinical or biochemical hypothyroidism. Minor abnormalities of the hypothalamo-pituitary-thyroid axis and of prolactin concentration may indicate a degree of hypothalamic suppression in these conditions.

We thank the technical staff of the steroid laboratory and radioimmunoassay unit, department of clinical chemistry, and of the centre for respiratory investigation, Royal Infirmary, Glasgow.

\section{References}

' Semple P d'A, Watson WS, Beastall GH, Bethel MIF, Grant JK, Hume R. Diet, absorption and hormone studies in relation to body weight in obstructive airways disease. Thorax 1979;34:783-8.

${ }^{2}$ Semple P d'A, Beastall GH, Watson WS, Hume R. Serum testosterone depression associated with hypoxia in respiratory failure. Clin Sci 1980;58:1056.

${ }^{3}$ Semple P d'A, Beastall GH, Watson WS, Hume R. Hypothalamo-pituitary dysfunction in respiratory hypoxia. Thorax 1981;36:605-9.

${ }^{4}$ Semple $\mathbf{P}$ d'A, Watson WS, Beastall GH, Hume $\mathbf{R}$. Endocrine and metabolic studies in unstable cor pulmonale. Thorax 1983;38:45-9.

5 Pugh LGCE. Physiological and medical aspects of the Himalayan scientific mountaineering expedition, 1960-61. Br Med J 1961;ii:621-7.

${ }^{6}$ Marmorston J, Weiner JM, Hopkins CE, Stern E. Abnormalities in urinary hormone patterns in lung cancer and emphysema. Cancer 1966;19:985-95.

' Semple P d'A, Beastall GH, Hume R. Male sexual dysfunction, low serum testosterone and respiratory hypoxia. Br J Sex Med 1980;62:48, 53.

${ }^{8}$ Medical Research Council Committee on Research into Chronic Bronchitis. Questionnaire on respiratory symptoms. London: Medical Research Council, 1966.

${ }^{9}$ Birath G, Kjellmer I, Sandqvist L. Spirometric studies in normal subjects. 2: Ventilatory capacity tests in adults. Acta Med Scand 1963;173:193-8.

10 Burrows B, Kasik JE, Niden AH, Barclay WR. Clinical usefulness of the single-breath pulmonary diffusing capacity test. Am Rev Respir Dis 1961;84:789-806.

" Cowden EA, Ratcliffe WA, Beastall GH, Ratcliffe JG. Laboratory assessment of prolactin status. Ann Clin Biochem 1979;16:113-21.
${ }^{12}$ Hall R, Amos J, Ormston B. Radioimmunoassay of human serum thyrotrophin. Br Med J 1971;i:582-5.

${ }^{13}$ Challand GS, Ratcliffe WA, Ratcliffe JG. Semiautomated radioimmunoassays for total serum thyroxine and triiodothyronine. Clin Chim Acta 1975;60:25-32.

14 Stearns EL, McDonnell JA, Kaufman BJ, Padua R, Lucan TS, Winter JSD, Fethan C. Declining testicular function with age: hormonal and clinical correlates. Am J Med 1974;57:761-6.

${ }^{15}$ Fairley KF, Barrie JU, Johnson W. Sterility and testicular atrophy related to cyclophosphamide therapy. Lancet 1972;i:568-9.

${ }^{16}$ De Groot GW, Faiman C, Winter JSD. Cyclophosphamide and the prepubertal gonad: a negative report. Pediatr Pharmacol Ther 1974;84:123-5.

${ }^{17}$ Monge CM, Monge CC. High altitude diseasesmechanism and management. Springfield, Illinois: Charles C Thomas, 1966.

${ }^{18}$ Heath D, Williams DR. Man at high altitude. Edinburgh: Churchill Livingstone, 1981.

${ }^{19}$ Donayre J. Life at high altitudes. Washington: Pan American Health Organisation, 1966. (PAHO Scientific publication No 140.)

${ }^{20}$ Guerra-Garcia R, Velasquez A, Coyotupa J. A test of endocrine gonadal function in men: urinary testosterone after injection of HCG. A different response from the high altitude native.J Clin Endocrinol Metab 1969;29:179-82.

${ }^{21}$ Sobrevilla LA, Midgley AR. Gonadotrophins. Los Altos, California: Geron X, 1968.

${ }^{22}$ Luton J-P, Thieblot P, Valcke J-C, Mahoudeau JA, Bricaire $\mathrm{H}$. Reversible gonadotrophin deficiency in male Cushing's disease. J Clin Endocrinol Metab 1977;45:255-60.

${ }^{23}$ Rose LI, Underwood RH, Newmark SR, Kisch ES, Williams GH. Pathophysiology of spironolactone induced gynaecomastia. Ann Intern Med 1977;87:398-403.

24 Riley A. Clinical pharmacology of drugs used in sexual medicine: drugs affecting prolactin secretion. $\mathrm{Br} J \mathrm{Sex}$ Med 1982;91:11-4.

${ }^{25}$ Hegeler S, Martensen M. Sexuality and ageing. Br J Sex Med 1978;5:16-9.

${ }^{26}$ Kinsey AC, Pomeroy WB, Martin CE. Sexual behaviour of the human male. Philadelphia: Sanders, 1948.

${ }^{27}$ Fischer C, Schiavi R, Lear H, Edwards A, Davis DM, Witkin AP. The assessment of nocturnal REM erections in the differential diagnosis of sexual impotence. J Sex Marit Ther 1975;4:277-9.

${ }^{28}$ Hosking DJ, Bennet T, Hampton JR, Evans DF, Clark AJ, Robertson G. Diabetic impotence: studies of nocturnal erection during REM sleep. $\mathrm{Br}$ Med $J$ 1979;ii:1394-6.

${ }^{24}$ Semple P d'A, Brown TM, Beastall GH, Semple CG. Sexual dysfunction and erectile impotence in chronic obstructive pulmonary disease. Chest $1983 ; 83: 587-8$. 